\title{
Fusagerins A-F, New Alkaloids from the Fungus Fusarium sp.
}

\author{
Hao Wen $\cdot$ Yan Li $\cdot$ Xingzhong Liu $\cdot$ \\ Wencai Ye $\cdot$ Xinsheng Yao $\cdot$ Yongsheng Che
}

Received: 9 August 2015/Accepted: 10 August 2015/Published online: 2 September 2015

(C) The Author(s) 2015. This article is published with open access at Springerlink.com

\begin{abstract}
Fusagerins A-F (1-6), six new alkaloids including a unique one with the rare a-( $N$-formyl)carboxamide moiety (1), a hydantoin (imidazolidin-2,4-dione) derivative (2), and four fungerin analogues (3-6), were isolated from the crude extract of the fungus Fusarium sp., together with the known compound fungerin (7). Compound $\mathbf{2}$ was isolated as a racemate and further separated into two enantiomers on a chiral HPLC column. The structures of 1-6 were determined mainly by NMR experiments, and the absolute configuration of $\mathbf{1}$ and $\mathbf{2}$ was assigned by electronic circular dichroism (ECD) calculations. Compound $\mathbf{7}$ showed antibacterial activity against Staphylococcus aureus and Streptococcus pneumoniae, and weak cytotoxicity against the T24 cells.
\end{abstract}

\section{Graphical Abstract}

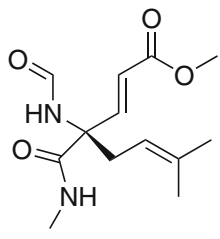

1<smiles>COC(=O)/C=C/C1NC(=O)N(C)C1=O</smiles>

2 (Racemate)<smiles>COC(=O)/C=C/c1ncn(C)c1/C=C/C(C)(C)O</smiles>

$3 \mathrm{R}=\mathrm{H}, 2 \mathrm{E}$ $4 \mathrm{R}=\mathrm{H}, 2 \mathrm{Z}$

Keywords Fusarium sp. $\cdot$ Alkaloids $\cdot$ Structure elucidation $\cdot$ Configuration determination

Electronic supplementary material The online version of this article (doi:10.1007/s13659-015-0067-1) contains supplementary material, which is available to authorized users.

\section{H. Wen $\cdot$ W. Ye $\cdot$ X. Yao $(\bowtie)$}

Institute of Traditional Chinese Medicine \& Natural Products,

College of Pharmacy, Jinan University, Guangzhou 510632,

People's Republic of China

e-mail: tyaoxs@jnu.edu.cn

\section{Y. Li · Y. Che $(\square)$}

State Key Laboratory of Toxicology \& Medical

Countermeasures, Beijing Institute of Pharmacology \&

Toxicology, Beijing 100850, People's Republic of China

e-mail: cheys@im.ac.cn
X. Liu

State Key Laboratory of Mycology, Institute of Microbiology,

Chinese Academy of Sciences, Beijing 100190, People's

Republic of China 


\section{Introduction}

Fungi are important sources of bioactive secondary metabolites [1], and those from special and competitive habitats are especially likely to produce structurally diverse and unique natural products due to their highly evolved secondary metabolism [2-4]. Based on this consideration, and our previous success in the discovery of new bioactive secondary metabolites from the of unique niches [5], a special group of fungi which were isolated from the fruiting body and larvae of Cordyceps sinensis were chemically investigated, leading to the isolation of a variety of cytotoxic natural products [6-9]. During the course, we also screened the fungal species isolated from the soil samples that were collected on the Qinghai-Tibetan plateau at altitudes above $3200 \mathrm{~m}$, the environment in which Cordyceps sinensis typically reside [10-13]. A strain of Fusarium sp. was such a fungus, and an EtOAc extract prepared from solid-substrate fermentation products of the fungus was subjected to chemical investigation. Fractionation of the crude extract afforded fusagerins A-F (Fig. 1; 1-6), six new alkaloids including a unique one with the rare a-( $N$-formyl)carboxamide moiety (1), a hydantoin (imidazolidin-2,4-dione) derivative (2), and four fungerin analogues (3-6), along with the known compound fungerin (Fig. 1; 7) [14]. Details of the isolation, structure elucidation, and biological activities of these compounds are reported herein.

\section{Results and Discussion}

The molecular formula of fusagerin A (1) was established as $\mathrm{C}_{13} \mathrm{H}_{20} \mathrm{~N}_{2} \mathrm{O}_{4}$ (five degrees of unsaturation) on the basis of HRESIMS $\left(\mathrm{m} / \mathrm{z} 269.1497[\mathrm{M}+\mathrm{H}]^{+}, \Delta-0.1 \mathrm{mmu}\right)$ and NMR data (Table 1). The ${ }^{1} \mathrm{H}$ and ${ }^{13} \mathrm{C}$ NMR spectra of $\mathbf{1}$ showed resonances for two exchangeable protons $\left(\delta_{\mathrm{H}} 7.64\right.$ and 7.34 , respectively), one aldehyde proton $\left(\delta_{\mathrm{H}} 8.19\right)$, four methyl groups including one $O$-methyl $\left(\delta_{\mathrm{H}} 3.71\right)$ and one $N$-methyl $\left(\delta_{\mathrm{H}} 2.75\right)$, one methylene unit, four olefinic carbons (three of which are protonated), one $s p^{3}$ quaternary carbon, and three carboxylic carbons $\left(\delta_{\mathrm{C}} 160.9,166.8\right.$, and
Table 1 NMR data for 1 (600 MHz, acetone- $\left.d_{6}\right)$

\begin{tabular}{llll}
\hline Position & $\delta_{\mathrm{H}}(J$ in Hz$)$ & $\delta_{\mathrm{C}}{ }^{\mathrm{a}}$ type & $\mathrm{HMBC}^{\mathrm{b}}$ \\
\hline 1 & & $166.8, \mathrm{qC}$ & \\
2 & $5.95, \mathrm{~d}(15.9)$ & $121.2, \mathrm{CH}$ & $1,3,4$ \\
3 & $7.20, \mathrm{~d}(15.9)$ & $148.3, \mathrm{CH}$ & $1,2,4,8,9$ \\
4 & & $64.0, \mathrm{qC}$ & \\
5 & $7.64, \mathrm{br} \mathrm{s}$ & & \\
6 & $8.19, \mathrm{~s}$ & $160.9, \mathrm{CH}$ & 4 \\
7 & $7.34, \mathrm{br} \mathrm{s}$ & & \\
8 & & $170.6, \mathrm{qC}$ & \\
$9 \mathrm{a}$ & $2.67, \mathrm{dd}(14.5,7.3)$ & $35.2, \mathrm{CH}_{2}$ & $3,4,8,10,11$ \\
$9 \mathrm{~b}$ & $2.99, \mathrm{dd}(14.5,7.3)$ & & \\
10 & $5.04, \mathrm{t},(7.3)$ & $118.1, \mathrm{CH}^{2}$ & $9,12,13$ \\
11 & & $136.6, \mathrm{qC}$ & \\
12 & $1.69, \mathrm{~s}$ & $26.1, \mathrm{CH}_{3}$ & $10,11,13$ \\
13 & $1.62, \mathrm{~s}$ & $18.1, \mathrm{CH}_{3}$ & $10,11,12$ \\
14 & $2.75, \mathrm{~d}(4.6)$ & $26.7, \mathrm{CH}_{3}$ & 8 \\
15 & $3.71, \mathrm{~s}$ & $51.7, \mathrm{CH}_{3}$ & 1 \\
\hline
\end{tabular}

${ }^{\text {a }}$ Recorded at $150 \mathrm{MHz}$

b HMBC correlations, optimized for $8 \mathrm{~Hz}$, are stated from proton(s) to the indicated carbons

170.6, respectively). These data accounted for all the five unsaturations of $\mathbf{1}$. Interpretation of the ${ }^{1} \mathrm{H}-{ }^{1} \mathrm{H}$ COSY NMR data of 1 revealed the presence of three isolated spinsystems, which were C-2-C-3, C-9-C-10, and N-7-C-14, respectively. In the $\mathrm{HMBC}$ spectrum of $\mathbf{1}$, cross peaks from the $\mathrm{H}-2$ and $\mathrm{H}-3$ olefinic protons to the carboxylic carbon at $166.8 \mathrm{ppm}(\mathrm{C}-1)$ established an $\alpha, \beta$-unsaturated ketone moiety (C-1-C-3). An HMBC correlation from the $O$ methyl proton signal $\mathrm{H}_{3}-15$ to the $\mathrm{C}-1$ carboxylic carbon located the $O$-methyl group at $\mathrm{C}-1$. Correlations of the $\mathrm{H}-10$ olefinic proton with $\mathrm{C}-12$ and $\mathrm{C}-13$, and of $\mathrm{H}_{3}-12$ and $\mathrm{H}_{3}-13$ with $\mathrm{C}-10$ and $\mathrm{C}-11$ established of a prenyl unit. In turn, a correlation from $\mathrm{H}_{3}-14$ to the $\mathrm{C}-8$ carboxylic carbon revealed the presence of the $\mathrm{C}-8 / \mathrm{N}-7$ amide bond in the structure. In addition, a one-bond coupling was noted between the C- 6 carbonyl resonance and the deshielded $\mathrm{H}-6$ proton resonance in the HSQC spectrum, suggesting
Fig. 1 Structures of metabolites 1-7 isolated from Fusarium sp.
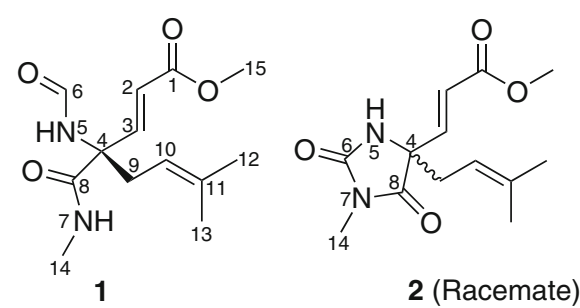

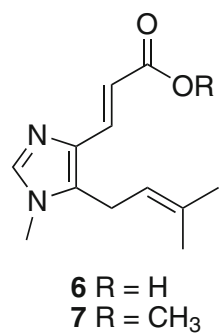


Fig. 2 The experimental CD spectrum of 1 (solid) and the calculated ECD spectra (dash) of two enantiomers $4 R-\mathbf{1}$ and $4 S-1$
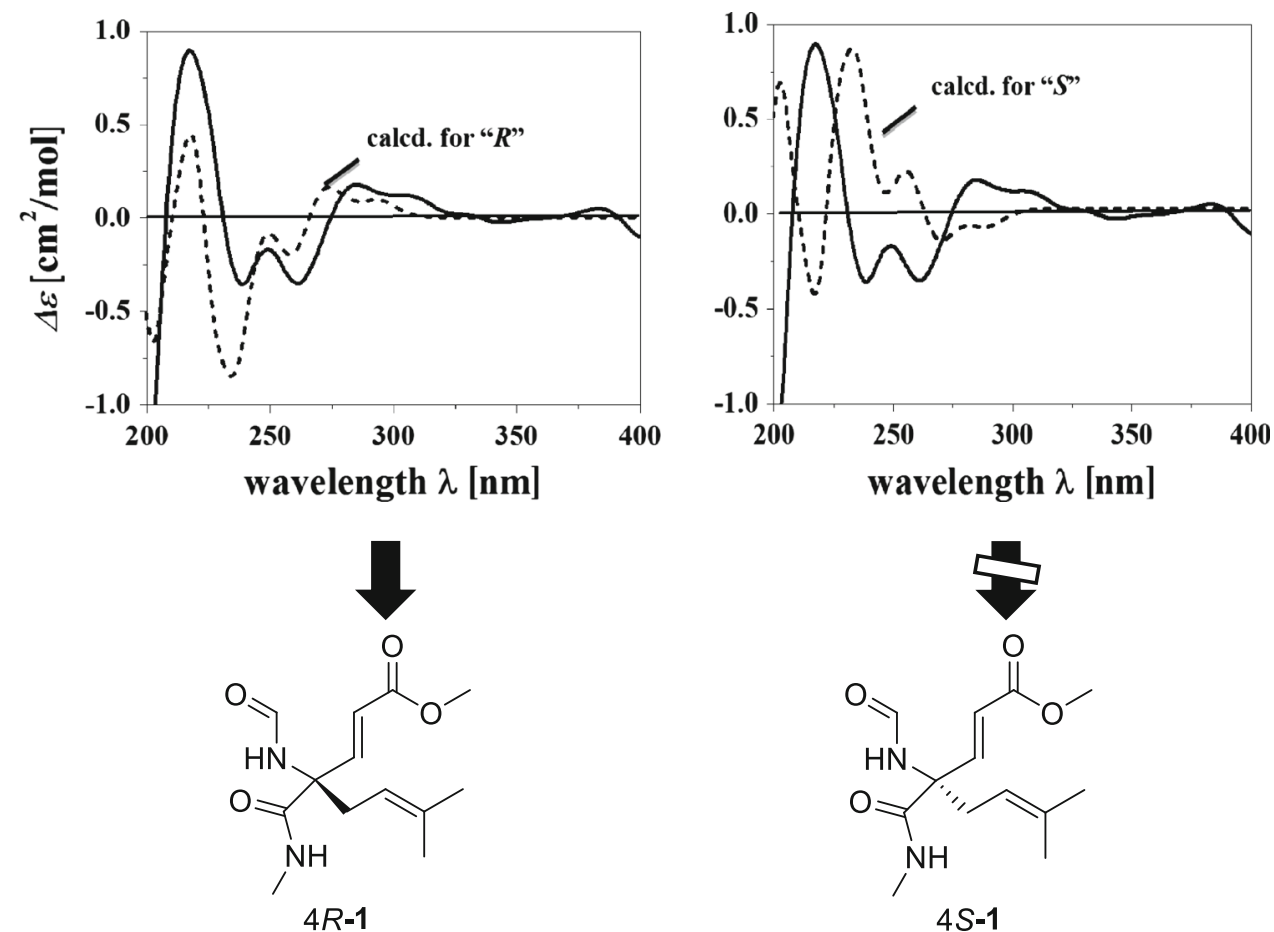

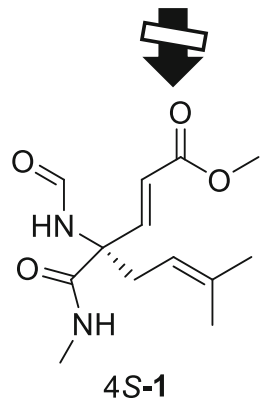

the presence of formamide functionality. The observation was also supported by a ${ }^{1} J_{\mathrm{C}, \mathrm{H}}$ value of $190 \mathrm{~Hz}$ measured in the HMBC spectrum, which was consistent with the reported values of 190 and $189 \mathrm{~Hz}[15,16]$. Key HMBC correlations from $\mathrm{H}-2, \mathrm{H}-3, \mathrm{H}-6$, and $\mathrm{H}-10$ to $\mathrm{C}-4$, and from $\mathrm{H}-3$ and $\mathrm{H}_{2}-9$ to $\mathrm{C}-8$ indicated that C-3, $N-5, \mathrm{C}-8$, and C-9 are all connected to $\mathrm{C}-4$. Although no HMBC correlations were observed for the two exchangeable protons, considering the relevant ${ }^{1} \mathrm{H}-{ }^{1} \mathrm{H}$ COSY correlation between $\mathrm{H}-7$ and $\mathrm{H}-14$, as well as the unsaturation requirement for $\mathbf{1}$, they were assigned as 5- and 7- $\mathrm{NH}$, respectively. On the basis of these data, the gross structure of fusagerin A was established as shown in Fig. 1.

The C-2/C-3 olefin was assigned the $E$-geometry based on a large coupling constant of $15.9 \mathrm{~Hz}$ observed for the corresponding olefinic protons. To determine the absolute configuration for the C-4 stereogenic center in fusagerin A (1), the theoretical CD spectra for the two enantiomers $4 R$ $\mathbf{1}$ and $4 S-1$ (Fig. 2) were predicted using quantum chemical calculations. Due to the flexible nature of the structure, the conformational species of each enantiomer were defined using the Random Search approach in Sybyl8.0 software. Six conformations were selected from 380 results within a range of $6 \mathrm{kcal} / \mathrm{mole}$ above the global minimum. For each conformer, the respective $\mathrm{CD}$ spectrum was calculated by TD-B3LYP/6-311++g(2d, p), after optimization using DFT at the B3LYP/6-31G(d) level in Gaussian09 program [17]. The overall calculated CD spectra were then generated according to Boltzmann weighting of each conformer,
Table 2 NMR data for $2\left(600 \mathrm{MHz}\right.$, acetone- $\left.d_{6}\right)$

\begin{tabular}{llll}
\hline Position & $\delta_{\mathrm{H}}(J$ in Hz $)$ & $\delta_{\mathrm{C}}$, type $^{\mathrm{a}}$ & $\mathrm{HMBC}^{\mathrm{b}}$ \\
\hline 1 & & $166.3, \mathrm{qC}$ & \\
2 & $6.13, \mathrm{~d}(15.8)$ & $122.4, \mathrm{CH}$ & $1,3,4$ \\
3 & $6.97, \mathrm{~d}(15.8)$ & $145.8, \mathrm{CH}$ & $1,2,4,8,9$ \\
4 & & $66.8, \mathrm{qC}$ & \\
5 & $7.57, \mathrm{dr} \mathrm{s}$ & 8 \\
6 & & $156.6, \mathrm{qC}$ & \\
7 & & & \\
8 & & $173.5, \mathrm{qC}$ & \\
$9 \mathrm{a}$ & $2.53, \mathrm{dd}(14.5,7.3)$ & $36.1, \mathrm{CH}_{2}$ & $3,4,8,10,11$ \\
$9 \mathrm{~b}$ & $2.70, \mathrm{dd}(14.5,7.3)$ & & \\
10 & $5.05, \mathrm{t}(7.3)$ & $116.5, \mathrm{CH}$ & $4,9,12,13$ \\
11 & & $138.2, \mathrm{qC}$ & \\
12 & $1.68, \mathrm{~s}$ & $26.0, \mathrm{CH}_{3}$ & $4,9,10,11,13$ \\
13 & $1.63, \mathrm{~s}$ & $18.2, \mathrm{CH}_{3}$ & $4,9,10,11,12$ \\
14 & $2.89, \mathrm{~s}$ & $24.6, \mathrm{CH}_{3}$ & 6,8 \\
15 & $3.72, \mathrm{~s}$ & $52.0, \mathrm{CH}_{3}$ & 1,2 \\
\hline
\end{tabular}

\footnotetext{
${ }^{\text {a }}$ Recorded at $150 \mathrm{MHz}$
}

b HMBC correlations, optimized for $8 \mathrm{~Hz}$, are stated from proton(s) to the indicated carbons

and were further compared to the experimental $\mathrm{CD}$ curve (Fig. 2). The experimental CD spectrum of 1 matched the ECD spectrum for $4 R-\mathbf{1}$, and was nearly opposite to that for $4 S-1$, leading to the deduction of the $4 R$ absolute configuration for $\mathbf{1}$. 
The elemental composition of fusagerin B (2) was deduced to be $\mathrm{C}_{13} \mathrm{H}_{18} \mathrm{~N}_{2} \mathrm{O}_{4}$ (six degrees of unsaturation) by HRESIMS analysis $\left(m / z \quad 267.1336 \quad[\mathrm{M}+\mathrm{H}]^{+}\right.$, $\Delta+0.3 \mathrm{mmu}$ ), two mass units less than that of $\mathbf{1}$. Analysis of the ${ }^{1} \mathrm{H}$ and ${ }^{13} \mathrm{C}$ NMR spectroscopic data of $\mathbf{2}$ (Table 2) revealed the presence of structural features similar to those found in 1, except that the signals for the H-6 aldehyde proton and the H-7 exchangeable proton in 1 were not observed, and the $\mathrm{N}$-methyl proton signal $\mathrm{H}_{3}-14$ was observed as a singlet instead of a doublet in the ${ }^{1} \mathrm{H}$ NMR spectrum of 2, implying that the C-6 and C-8 carboxylic carbons are connected to $N-7$ to form a 3-methylimidazolidine-2,4-dione moiety. This postulation was also supported by the HMBC correlations from $\mathrm{H}_{3}-14$ to $\mathrm{C}-6$ and C-8. On the basis of these data, the planar structure of $\mathbf{2}$ was established as depicted (Fig. 1).

Despite the presence of a stereogenic center at C-4, the measured optical rotation value of fusagerin B (2) was zero, and no Cotton effect was observed in its CD spectrum, suggesting that $\mathbf{2}$ is a racemate. A portion of $\mathbf{2}$ was separated using HPLC on a chiral column to afford two enantiomers, (-)-fusagerin B (Figs. 3, 2a) and (+)-fusagerin B (Figs. 3, 2b), with the measured specific optical rotation values of -16 and +16 , respectively ( $c 0.10$, $\mathrm{MeOH})$. The absolute configurations of $\mathbf{2 a}$ and $\mathbf{2 b}$ were deduced by comparison of the experimental and simulated ECD spectra for enantiomers $4 R-2$ and $4 S-2$ (Fig. 4). The

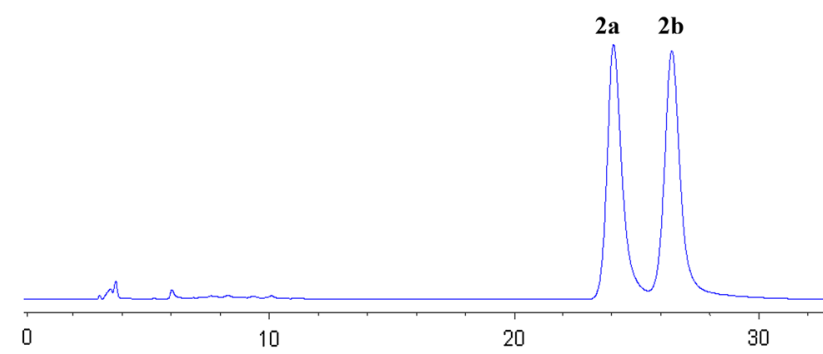

Fig. 3 The HPLC chromatogram of 2 using a Kromasil 5-CelluCoat $\mathrm{RP}$ column $(4.6 \times 250 \mathrm{~mm}, 5 \mu \mathrm{m})$ eluted with $\mathrm{CH}_{3} \mathrm{CN} / \mathrm{H}_{2} \mathrm{O}(30: 70$, $\mathrm{v} / \mathrm{v}$; flow rate $0.5 \mathrm{~mL} / \mathrm{min}$; UV detection at $210 \mathrm{~nm}$ ) experimental CD spectra of $\mathbf{2 a}$ and $\mathbf{2} \mathbf{b}$ matched the calculated ECD curves of $4 S-\mathbf{2}$ and $4 R-\mathbf{2}$, respectively, leading to the deduction of $4 S$ for (-)-fusagerin $\mathrm{B}(\mathbf{2 a})$, and $4 R$ configuration for $(+)$-fusagerin $\mathrm{B}(\mathbf{2 b})$.

Fusagerin $\mathrm{C}(3)$ gave a pseudomolecular ion $[\mathrm{M}+\mathrm{H}]^{+}$ peak at $m / z 251.1388(\Delta+0.2 \mathrm{mmu})$ by HRESIMS, consistent with the molecular formula $\mathrm{C}_{13} \mathrm{H}_{18} \mathrm{~N}_{2} \mathrm{O}_{3}$ (six degrees of unsaturation). Analysis of its ${ }^{1} \mathrm{H}$ and ${ }^{13} \mathrm{C} \mathrm{NMR}$ data (Table 3 ) revealed structural similarity to the co-isolated known compound fungerin (7) [14], except that the C-11 olefinic carbon in 7 was reduced to an oxygenated $s p^{3}$ quaternary carbon $\left(\delta_{\mathrm{C}} 70.8\right)$, and the C-9 methylene carbon in 7 was oxidized to an olefinic carbon $\left(\delta_{\mathrm{H}} / \delta_{\mathrm{C}} 6.66 / 112.3\right)$, which were confirmed by the ${ }^{1} \mathrm{H}-{ }^{1} \mathrm{H}$ COSY NMR correlations of $9-\mathrm{H}$ with $10-\mathrm{H}$, and $\mathrm{HMBC}$ cross peaks from the exchangeable proton $\mathrm{OH}-11$ to $\mathrm{C}-10, \mathrm{C}-12$, and $\mathrm{C}-13$. The C-2/C-3 and C-9/C-10 olefins were all assigned the $E$-geometry based on the large coupling constants observed for the relevant olefinic protons $(15.3$ and $16.2 \mathrm{~Hz}$, respectively). Therefore, the structure of $\mathbf{3}$ was determined as shown in Fig. 1.

The molecular formula of fusagerin $\mathrm{D}$ (4) was determined to be $\mathrm{C}_{13} \mathrm{H}_{18} \mathrm{~N}_{2} \mathrm{O}_{3}$ on the basis of HRESIMS $(\mathrm{m} / \mathrm{z}$ $\left.251.1391[\mathrm{M}+\mathrm{H}]^{+}, \Delta-0.1 \mathrm{mmu}\right)$ and NMR data (Table 3), which is the same as that of $\mathbf{3}$, implying isomeric relationship between the two compounds. The ${ }^{1} \mathrm{H}$ and ${ }^{13} \mathrm{C}$ NMR spectra of $\mathbf{4}$ showed nearly identical resonances to those of 3, except that the chemical shifts for the C-2/C-3 olefin $\left(\delta_{\mathrm{H}} / \delta_{\mathrm{C}} 6.52 / 115.1\right.$ and $7.64 / 136.7$ in $3 ; 5.74 / 118.2$ and 6.68/129.5 in 4) were significantly different. Interpretation of the 2D NMR data of $\mathbf{4}$ established the same planar structure as $\mathbf{3}$, and a small coupling constant of $12.1 \mathrm{~Hz}$ observed between $\mathrm{H}-2$ and $\mathrm{H}-3$ in $\mathbf{4}$ compared to $15.3 \mathrm{~Hz}$ in $\mathbf{3}$, indicating that $\mathbf{4}$ is the $2 Z$ isomer of $\mathbf{3}$.

Fusagerin E (5) was assigned a molecular formula of $\mathrm{C}_{13} \mathrm{H}_{18} \mathrm{~N}_{2} \mathrm{O}_{4}$ (six degrees of unsaturation) by HRESIMS $\left(\mathrm{m} / z 267.1339[\mathrm{M}+\mathrm{H}]^{+}, \Delta 0 \mathrm{mmu}\right)$, containing one more oxygen atom than that of 3 . Analysis of its NMR data (Table 3) revealed structural characteristics similar to those of $\mathbf{3}$, but the ${ }^{13} \mathrm{C}$ NMR chemical shift of C-11 in $\mathbf{5}\left(\delta_{\mathrm{C}} 82.1\right)$
Fig. 4 The experimental CD spectrum of 2 (solid) and the calculated ECD spectra (dash) of two enantiomers, 2a (4S-2) and $2 \mathbf{b}(4 R-2)$
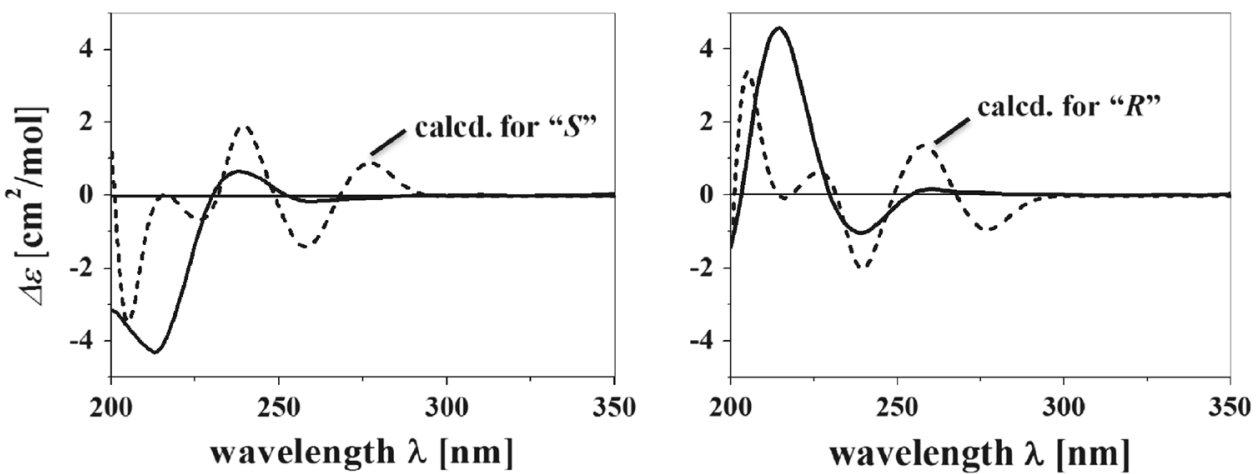
Table 3 NMR data for 3-6

\begin{tabular}{|c|c|c|c|c|c|c|c|c|}
\hline \multirow[t]{2}{*}{ Position } & \multicolumn{2}{|l|}{3} & \multicolumn{2}{|l|}{4} & \multicolumn{2}{|l|}{5} & \multicolumn{2}{|l|}{6} \\
\hline & $\delta_{\mathrm{H}}^{\mathrm{a}}(J$ in $\mathrm{Hz})$ & $\delta_{\mathrm{C}}^{\mathrm{b}}$ & $\delta_{\mathrm{H}}^{\mathrm{a}}(J$ in $\mathrm{Hz})$ & $\delta_{\mathrm{C}}^{\mathrm{b}}$ & $\delta_{\mathrm{H}}^{\mathrm{c}}(J$ in $\mathrm{Hz})$ & $\delta_{\mathrm{C}}^{\mathrm{d}}$ & $\delta_{\mathrm{H}}^{\mathrm{e}}(J$ in $\mathrm{Hz})$ & $\delta_{\mathrm{C}}^{\mathrm{f}}$ \\
\hline 1 & & $168.3, \mathrm{qC}$ & & $168.8, \mathrm{qC}$ & & $168.4, \mathrm{qC}$ & & $168.2, \mathrm{qC}$ \\
\hline 2 & $6.52, \mathrm{~d}(15.3)$ & $115.1, \mathrm{CH}$ & $5.74, \mathrm{~d}(12.1)$ & $118.2, \mathrm{CH}$ & $6.62, \mathrm{~d}(15.5)$ & $115.9, \mathrm{CH}$ & $6.23, \mathrm{~d}(15.2)$ & 114.0, $\mathrm{CH}$ \\
\hline 3 & $7.64, \mathrm{~d}(15.3)$ & 136.7, CH & $6.68, \mathrm{~d}(12.1)$ & $129.5, \mathrm{CH}$ & $7.59, \mathrm{~d}(15.5)$ & $135.1, \mathrm{CH}$ & $7.47, \mathrm{~d}(15.2)$ & $135.3, \mathrm{CH}$ \\
\hline 4 & & $135.8, \mathrm{qC}$ & & $135.9, \mathrm{qC}$ & & 135.7, qC & & 133.0, qC \\
\hline 6 & $7.56, \mathrm{~s}$ & $140.6, \mathrm{CH}$ & $7.43, \mathrm{~s}$ & $138.9, \mathrm{CH}$ & $7.47, \mathrm{~s}$ & $139.2, \mathrm{CH}$ & $7.61, \mathrm{~s}$ & $139.1, \mathrm{CH}$ \\
\hline 8 & & 133.4, qC & & $130.8, \mathrm{qC}$ & & $131.8, \mathrm{qC}$ & & 134.1, qC \\
\hline 9 & $6.66, \mathrm{~d}(16.2)$ & $112.3, \mathrm{CH}$ & $6.57, \mathrm{~d}(16.1)$ & $112.8, \mathrm{CH}$ & $6.44, \mathrm{~d}(16.6)$ & $114.8, \mathrm{CH}$ & $3.43, \mathrm{~d}(7.0)$ & 21.6, $\mathrm{CH}_{2}$ \\
\hline 10 & $6.28, \mathrm{~d}(16.2)$ & $146.2, \mathrm{CH}$ & $6.16, \mathrm{~d}(16.1)$ & $144.8, \mathrm{CH}$ & $6.14, d(16.6)$ & $140.9, \mathrm{CH}$ & $5.05, \mathrm{t}(7.0)$ & $120.0, \mathrm{CH}$ \\
\hline 11 & & 70.9, qC & & $70.8, \mathrm{qC}$ & & $82.1, \mathrm{qC}$ & & 133.0, qC \\
\hline 12 & $1.40, \mathrm{~s}$ & $30.3, \mathrm{CH}_{3}$ & $1.37, \mathrm{~s}$ & $30.4, \mathrm{CH}_{3}$ & $1.52, \mathrm{~s}$ & $24.4, \mathrm{CH}_{3}$ & $1.68, \mathrm{~s}$ & $25.3, \mathrm{CH}_{3}$ \\
\hline 13 & $1.40, \mathrm{~s}$ & $30.3, \mathrm{CH}_{3}$ & $1.37, \mathrm{~s}$ & $30.4, \mathrm{CH}_{3}$ & $1.52, \mathrm{~s}$ & $24.4, \mathrm{CH}_{3}$ & $1.73, \mathrm{~s}$ & $17.7, \mathrm{CH}_{3}$ \\
\hline 14 & $3.70, \mathrm{~s}$ & $32.7, \mathrm{CH}_{3}$ & $3.65, \mathrm{~s}$ & $32.3, \mathrm{CH}_{3}$ & $3.65, \mathrm{~s}$ & 32.6, $\mathrm{CH}_{3}$ & $3.53, \mathrm{~s}$ & $31.2, \mathrm{CH}_{3}$ \\
\hline 15 & $3.70, \mathrm{~s}$ & $51.4, \mathrm{CH}_{3}$ & $3.63, \mathrm{~s}$ & $51.1, \mathrm{CH}_{3}$ & $3.80, \mathrm{~s}$ & $51.5, \mathrm{CH}_{3}$ & & \\
\hline OH-1 & & & & & & & $12.07, \mathrm{~s}$ & \\
\hline $\mathrm{OH}-11^{\mathrm{g}}$ & $4.89, \mathrm{~s}$ & & $4.79, \mathrm{~s}$ & & & & & \\
\hline $\mathrm{OOH}-11^{\mathrm{a}}$ & & & & & 10.41 , br s & & & \\
\hline
\end{tabular}

\footnotetext{
${ }^{\text {a }}$ Recorded at $500 \mathrm{MHz}$ in acetone- $d_{6}$

${ }^{\mathrm{b}}$ Recorded at $125 \mathrm{MHz}$ in acetone- $d_{6}$

c Recorded at $500 \mathrm{MHz}$ in $\mathrm{CDCl}_{3}$

d Recorded at $125 \mathrm{MHz}$ in $\mathrm{CDCl}_{3}$

e Recorded at $400 \mathrm{MHz}$ in DMSO- $d_{6}$

${ }^{\mathrm{f}}$ Recorded at $100 \mathrm{MHz}$ in DMSO- $d_{6}$

g Recorded at $100 \mathrm{MHz}$ in DMSO- $d_{6}$
}

was significantly downfield compared to that in $\mathbf{3}\left(\delta_{\mathrm{C}} 70.9\right)$, suggesting that the C-11 hydroxy group was oxidized to a peroxy unit. A similar peroxy moiety was also found in the known compounds, peroxylippidulcine A [18] and bruguierin C [19]. The absolute configuration of $\mathbf{5}$ was deduced as shown by analogy to $\mathbf{3}$ and $\mathbf{4}$.

The molecular formula of fusagerin $\mathrm{F}(\mathbf{6})$ was established as $\mathrm{C}_{12} \mathrm{H}_{16} \mathrm{~N}_{2} \mathrm{O}_{2}$ (six degrees of unsaturation) on the basis of HRESIMS $\left(\mathrm{m} / z 221.1293[\mathrm{M}+\mathrm{H}]^{+}, \Delta-0.8\right.$ $\mathrm{mmu}$ ), which is 14 mass units less than that of the known compound fungerin (7) [14]. The NMR data of 6 (Table 3) are nearly identical to those of 7 , except that the C-15 methyl group $\left(\delta_{\mathrm{H}} / \delta_{\mathrm{C}} 3.77 / 51.4\right)$ in 7 was replaced by a proton $\left(\delta_{\mathrm{H}} 12.07\right)$, indicating that 6 bears a free carboxylic acid moiety at $\mathrm{C}-2$.

Compounds 1-7 were tested for their antimicrobial activities against a panel of bacteria and fungi [20, 21], Compounds 1-6 did not show noticeable in vitro antibacterial or antifungal activities against the above-mentioned organisms (Experimental Section; $\mathrm{IC}_{50}>50 \mu \mathrm{M}$ ). Only fungerin (7) showed weak antibacterial activity against Staphylococcus aureus (ATCC 6538) and Streptococcus pneumoniae (CGMCC 1.1692), with $\mathrm{IC}_{50}$ values of 33.8 and $34.5 \mu \mathrm{M}$, respectively, while the positive control ampicillin showed an $\mathrm{IC}_{50}$ value of $0.26 \mu \mathrm{M}$. Compounds 1-7 were also tested for cytotoxicity against a panel of six human tumor cell lines, HeLa (cervical epithelial cells), A549 (lung carcinoma epithelial cells), MCF-7 (breast cancer cells), HCT116 (colon cancer cells), SW480 (colon cancer cells), and T24 (bladder cancer cells). Compounds 1-6 did not show detectable cytotoxicity against the six cell lines at a concentration of $20 \mu \mathrm{g} / \mathrm{mL}$, whereas compound 7 showed weak cytotoxic effect on the T24 cells, with an $\mathrm{IC}_{50}$ value of $42.2 \mu \mathrm{M}$ (the positive control cisplatin showed an $\mathrm{IC}_{50}$ value of $6.71 \mu \mathrm{M}$.

Fusagerin A (1) is the first example of naturally occurring $\alpha$-( $N$-formyl)carboxamide, which was only synthesized in situ previously from $\alpha$-aminonitriles using formicacetic anhydride [22]. Fusagerin B (2) is a new member of the extensively studied hydantoin (2,4-imidazolidindione) class of natural products which possess a variety of pharmacological properties, such as anticonvulsant [23-26], antitumor [27, 28], anti-HIV [29], antiarrhytmic [30], antihypertensive [31], hypolipidemic [32], antituberculosis 
<smiles>[Y7]C(C)=CC[C@H]1NC(=O)N(C)C1=O</smiles><smiles></smiles><smiles>COC(=O)/C=C/C1(C/C=C(\C)C[PH+])N=CN(C)C1O</smiles>

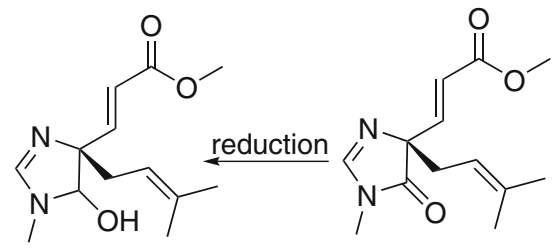

Scheme 1 Hypothetical biosynthetic pathways for compounds 1-6

[33], and antifungal activities [34]. However, 2 differs from the known precedents by having different substituents on the 2,4-imidazolidindione ring. The only two fungal metabolites incorporating the hydantoin moiety were both isolated from marine-derived fungi $[35,36]$. Other examples of this class of natural products were mainly isolated from marine organisms including exiguamine A [37], agesamides $\mathrm{A}$ and $\mathrm{B}$ [38], naamidines and isonaamidines [39-47], parazoanthines A-E [48], and 5-methoxy-5-(4methoxyphenyl)-3-methyl-2,4-imidazolidinedione [49]. Compounds 3-6 are closely related to fungerin (7) [14], all possessing the imidazole ring. To our knowledge, only three fungerin derivatives have been reported including visoltricin [50], and hydroxyfungerins $\mathrm{A}$ and $\mathrm{B}$ [51]. Compounds 3-6 differ from the above-mentioned natural products mainly on the identities of the side chains. The plausible biogenetic pathways for compounds 1-6 are illustrated in Scheme 1.

\section{Experimental Section}

\subsection{General Experimental Procedures}

Optical rotations were measured on a polAAr3005 polarimeter, and UV data were recorded on a Shimadzu Biospec-1601 spectrophotometer. The CD spectra were recorded on a JASCO J-815 spectropolarimeter. IR data were recorded using a Nicolet Magna-IR 750 spectrophotometer. ${ }^{1} \mathrm{H}$ and ${ }^{13} \mathrm{C}$ NMR data were acquired with Varian Mercury-400, -500, and -600 spectrometers using the solvent signals (acetone- $d_{6}: \delta_{\mathrm{H}} 2.05 / \delta_{\mathrm{C}} 29.8,206.1$; DMSO$\left.d_{6}: \delta_{\mathrm{H}} 2.49 / \delta_{\mathrm{C}} 39.5 ; \mathrm{CDCl}_{3}: \delta_{\mathrm{H}} 7.26 / \delta_{\mathrm{C}} 76.7\right)$ as references. The HSQC and HMBC experiments were optimized for 145.0 and $8.0 \mathrm{~Hz}$, respectively. ESIMS and HRESIMS data were obtained using an Agilent Accurate-Mass-Q-TOF LC/ MS 6520 instrument equipped with an electrospray ionization (ESI) source. The fragmentor and capillary voltages were kept at 125 and $3500 \mathrm{~V}$, respectively. Nitrogen was supplied as the nebulizing and drying gas. The temperature of the drying gas was set at $300{ }^{\circ} \mathrm{C}$. The flow rate of the drying gas and the pressure of the nebulizer were $10 \mathrm{~L} / \mathrm{min}$ and $10 \mathrm{psi}$, respectively. All MS experiments were performed in positive ion mode. Full-scan spectra were acquired over a scan range of $\mathrm{m} / \mathrm{z}, 100-1000$ at 1.03 spectra/ s. HPLC separations were performed on an Agilent 1260 instrument (Agilent, USA) equipped with a variable wavelength UV detector. Chiral HPLC analysis and separation were performed on a Kromasil 5-CelluCoat RP column $(4.6 \times 250 \mathrm{~mm} ; 5 \mu \mathrm{m}$; AkzoNobel $)$.

\subsection{Fungal Material}

The culture of Fusarium sp. was isolated from a soil sample collected on the Qinghai-Tibetan plateau at an altitude of $3800 \mathrm{~m}$, in May, 2008. The isolate was identified based on morphology and sequence (Genbank Accession No. JQ284030) analysis of the ITS region of the rDNA. The fungal strain was cultured on slants of potato dextrose agar (PDA) at $25{ }^{\circ} \mathrm{C}$ for 10 days. Agar plugs were cut into small pieces (about $0.5 \times 0.5 \times 0.5 \mathrm{~cm}^{3}$ ) under aseptic conditions, 15 pieces were used to inoculate in three Erlenmeyer flasks $(250 \mathrm{~mL})$, each containing $50 \mathrm{~mL}$ of media ( $0.4 \%$ glucose, $1 \%$ malt extract, and $0.4 \%$ yeast extract), and the final $\mathrm{pH}$ of the media was adjusted to 6.5 . After sterilization, three flasks of the inoculated media were incubated at $25{ }^{\circ} \mathrm{C}$ on a rotary shaker at $170 \mathrm{rpm}$ for 5 days to prepare the seed culture. Spore inoculum was prepared by suspending the seed culture in sterile, distilled $\mathrm{H}_{2} \mathrm{O}$ to give a final spore/cell suspension of $1 \times 10^{6} / \mathrm{mL}$. 
Fermentation was carried out in eight Fernbach flasks $(500 \mathrm{~mL})$, each containing $80 \mathrm{~g}$ of rice. Distilled $\mathrm{H}_{2} \mathrm{O}$ $(120 \mathrm{~mL})$ was added to each flask, and the contents were soaked overnight before autoclaving at $15 \mathrm{psi}$ for $30 \mathrm{~min}$. After cooling to room temperature, each flask was inoculated with $5.0 \mathrm{~mL}$ of the spore inoculum and incubated at $25{ }^{\circ} \mathrm{C}$ for 40 days.

\subsection{Extraction and Isolation}

The fermented material was extracted repeatedly with EtOAc $(4 \times 1.0 \mathrm{~L})$, and the organic solvent was evaporated to dryness under vacuum to afford the crude extract $(50.0 \mathrm{~g})$, which was fractionated by silica gel VLC using petroleum etherEtOAc-MeOH gradient elution. The fraction $(150 \mathrm{mg}$ ) eluted with 10:90 petroleum ether-EtOAc was separated by Sephadex LH-20 column chromatography (CC) eluting with $\mathrm{MeOH}$. The resulting subfractions were combined and further purified by semipreparative RP HPLC (Agilent Zorbax SB$\mathrm{C}_{18}$ column; $5 \mu \mathrm{m} ; 9.4 \times 250 \mathrm{~mm} ; 50 \% \mathrm{MeOH}$ in $\mathrm{H}_{2} \mathrm{O}$ for $30 \mathrm{~min} ; 2 \mathrm{~mL} / \mathrm{min})$ to afford fusagerins $\mathrm{C}\left(\mathbf{3} ; 2.0 \mathrm{mg}, t_{\mathrm{R}}\right.$ $15.80 \mathrm{~min}), \mathrm{D}\left(\mathbf{4} ; 4.0 \mathrm{mg}, t_{\mathrm{R}} 16.07 \mathrm{~min}\right)$, and B $\left(2 ; 3.4 \mathrm{mg}, t_{\mathrm{R}}\right.$ $28.10 \mathrm{~min})$. The fraction $(150 \mathrm{mg}$ ) eluted with EtOAc was also separated again by Sephadex LH-20 CC eluting with $\mathrm{MeOH}$. The resulting subfractions were combined and further purified by RP HPLC $\left(20 \% \mathrm{MeOH}\right.$ in $\mathrm{H}_{2} \mathrm{O}$ for 2 min, followed by $20-100 \%$ over $50 \mathrm{~min} ; 2 \mathrm{~mL} / \mathrm{min}$ ) to afford fusagerins $\mathrm{E}\left(\mathbf{5} ; 6.3 \mathrm{mg}, t_{\mathrm{R}} 29.40 \mathrm{~min}\right)$ and $\mathrm{A}\left(\mathbf{1} ; 3.0 \mathrm{mg}, t_{\mathrm{R}}\right.$ $32.69 \mathrm{~min})$. The fraction $(120 \mathrm{mg}$ ) eluted with 99:1 EtOAc$\mathrm{MeOH}$ was further fractionated by Sephadex LH-20 CC eluting with $\mathrm{MeOH}$. The combined subfractions was purified by RP HPLC $\left(65 \% \mathrm{MeOH}\right.$ in $\mathrm{H}_{2} \mathrm{O}$ for 15 min, followed by $65-100 \%$ over $60 \mathrm{~min} ; 2 \mathrm{~mL} / \mathrm{min})$ to afford fungerin $(\mathbf{7}$; $\left.74.8 \mathrm{mg}, t_{\mathrm{R}} 16.32 \mathrm{~min}\right)$. The $(140 \mathrm{mg})$ fraction eluted with $\mathrm{MeOH}$ was separated by Sephadex LH-20 CC eluting with $\mathrm{MeOH}$, and the resulting subfractions were purified by RP HPLC $\left(30 \% \mathrm{MeOH}\right.$ in $\mathrm{H}_{2} \mathrm{O}$ for $10 \mathrm{~min}$, followed by $30-100 \%$ over $20 \mathrm{~min} ; 2 \mathrm{~mL} / \mathrm{min})$ to afford fusagerin $\mathrm{F}$ (6; $\left.4.0 \mathrm{mg}, t_{\mathrm{R}} 15.24 \mathrm{~min}\right)$. A portion of compound 2 was separated using a Kromasil 5-CelluCoat RP column (30\% $\mathrm{CH}_{3} \mathrm{CN}$ in $\mathrm{H}_{2} \mathrm{O}$ for $30 \mathrm{~min} ; 0.5 \mathrm{~mL} / \mathrm{min}$ ) to afford (-)-fusagerin $\mathrm{B}\left(\mathbf{2 a} ; 1.0 \mathrm{mg}, t_{\mathrm{R}} 24.30 \mathrm{~min}\right)$ and (+)-fusagerin $\mathrm{B}\left(\mathbf{2 b} ; 1.0 \mathrm{mg}, t_{\mathrm{R}} 26.78 \mathrm{~min}\right)$.

\subsubsection{Fusagerin A (1)}

Pale yellow oil; $[\alpha]_{\mathrm{D}}^{22}+5.6($ c 0.2, $\mathrm{MeOH}) ; \mathrm{UV}(\mathrm{MeOH})$ $\lambda_{\max }(\log \varepsilon) 210$ (2.07), 217 (1.96), 238 (1.73), 285 (1.28) $\mathrm{nm} ; \mathrm{CD}\left(c 3.7 \times 10^{-3} \mathrm{M}, \mathrm{MeOH}\right) \lambda_{\max }(\Delta \varepsilon) 218(+7.28)$, 239 (-2.89), 249 (-1.36), $261(-2.85), 285(+1.45)$; IR (neat) $v_{\max } 3325$ (br), 2953, 1723, 1666, 1532, 1438, 1384, $1313,1277,1200,1178 \mathrm{~cm}^{-1} ;{ }^{1} \mathrm{H},{ }^{13} \mathrm{C}$ NMR, and $\mathrm{HMBC}$ data see Table 1; HRESIMS m/z 269.1497 (calcd. for $\mathrm{C}_{13} \mathrm{H}_{21} \mathrm{~N}_{2} \mathrm{O}_{4}, 269.1496$ ).

\subsubsection{Fusagerin $B(2)$}

Colorless oil; UV (MeOH) $\lambda_{\max }(\log \varepsilon) 215$ (2.62), 237 (1.99) nm; IR (neat) $v_{\max } 3311$ (br), 2929, 1782, 1721, 1658, 1460, 1395, 1317, 1278, 1199, 1176, $1028 \mathrm{~cm}^{-1} ;{ }^{1} \mathrm{H}$, ${ }^{13} \mathrm{C}$ NMR, and HMBC data see Table 2. HRESIMS $\mathrm{m} / \mathrm{z}$ 267.1336 (calcd. for $\mathrm{C}_{13} \mathrm{H}_{19} \mathrm{~N}_{2} \mathrm{O}_{4}, 267.1339$ ).

\subsection{3 (-)-Fusagerin A (2a)}

Colorless oil; $\quad[\alpha]_{\mathrm{D}}^{22}-16.0 \quad(c \quad 0.1, \quad \mathrm{MeOH}) ; \quad \mathrm{CD}$ $\left(c 3.8 \times 10^{-3} \mathrm{M}, \mathrm{MeOH}\right) \lambda_{\max }(\Delta \varepsilon) 213(-4.32), 238$ (+0.65), 260 (-0.18); UV, IR, ${ }^{1} \mathrm{H},{ }^{13} \mathrm{C}$ NMR, HMBC, and HRESIMS data were the same as 2.

\subsection{4 (+)-Fusagerin $(2 \boldsymbol{b})$}

Colorless oil; $\quad[\alpha]_{\mathrm{D}}^{22}+16.0 \quad\left(\begin{array}{ccc}c & 0.1, & \mathrm{MeOH}\end{array}\right) ; \quad \mathrm{CD}$ $\left(c 3.8 \times 10^{-3} \mathrm{M}, \mathrm{MeOH}\right) \lambda_{\max }(\Delta \varepsilon) 216(+4.58), 239$ (-1.05), $260(+0.15)$; UV, IR, ${ }^{1} \mathrm{H},{ }^{13} \mathrm{C}$ NMR, HMBC, and HRESIMS data were the same as 2.

\subsubsection{Fusagerin $C(3)$}

Colorless oil; UV $(\mathrm{MeOH}) \lambda_{\max }(\log \varepsilon) 237$ (2.37), 308 (2.39) nm; IR (neat) $v_{\max } 3389$ (br), 2972, 1720, 1632, $1509,1438,1377,1302,1278,1230,1197,1173 \mathrm{~cm}^{-1} ;{ }^{1} \mathrm{H}$ and ${ }^{13} \mathrm{C}$ NMR data see Table 3; HMBC data (acetone- $d_{6}$, $500 \mathrm{MHz}) \mathrm{H}-2 \rightarrow \mathrm{C}-1, \mathrm{C}-3, \mathrm{C}-4$; H-3 $\rightarrow \mathrm{C}-1, \mathrm{C}-2, \mathrm{C}-4$, C-8; H-6 $\rightarrow$ C-4, C-8; H-9 $\rightarrow$ C-4, C-8, C-10, C-11, C-12, $\mathrm{C}-13 ; \mathrm{H}-10 \rightarrow \mathrm{C}-8, \mathrm{C}-11, \mathrm{C}-12, \mathrm{C}-13 ; \mathrm{H}_{3}-12 \rightarrow \mathrm{C}-9$, $\mathrm{C}-10, \mathrm{C}-11, \mathrm{C}-13 ; \mathrm{H}_{3}-13 \rightarrow \mathrm{C}-9, \mathrm{C}-10, \mathrm{C}-11, \mathrm{C}-12$; $\mathrm{H}_{3}-14 \rightarrow \mathrm{C}-6, \mathrm{C}-8 ; \mathrm{H}_{3}-15 \rightarrow \mathrm{C}-1$; (DMSO- $d_{6}, 600 \mathrm{MHz}$ ) $\mathrm{OH}-11 \rightarrow \mathrm{C}-10, \mathrm{C}-11, \mathrm{C}-12$, C-13; HRESIMS $\mathrm{m} / \mathrm{z}$ 251.1388 (calcd. for $\mathrm{C}_{13} \mathrm{H}_{19} \mathrm{~N}_{2} \mathrm{O}_{3}, 251.1390$ ).

\subsubsection{Fusagerin D (4)}

Colorless oil; UV (MeOH) $\lambda_{\max }(\log \varepsilon) 238$ (2.56), 298 (2.41) nm; IR (neat) $v_{\max } 3381$ (br), 2972, 1708, 1631, 1511, 1436, 1376, 1302, 1264, 1232, 1196, $1172 \mathrm{~cm}^{-1} ;{ }^{1} \mathrm{H}$ and ${ }^{13} \mathrm{C}$ NMR data see Table 3 ; HMBC data (acetone- $d_{6}$, $500 \mathrm{MHz}) \mathrm{H}-2 \rightarrow \mathrm{C}-1, \mathrm{C}-3$; H-3 $\rightarrow \mathrm{C}-1, \mathrm{C}-2$, C-4, C-8; H-6 $\rightarrow$ C-4, C-8; H-9 $\rightarrow$ C-4, C-8, C-10, C-11, C-12, $\mathrm{C}-13 ; \mathrm{H}-10 \rightarrow \mathrm{C}-8, \mathrm{C}-11, \mathrm{C}-12, \mathrm{C}-13 ; \mathrm{H}_{3}-12 \rightarrow \mathrm{C}-9$, C-10, C-11, C-13; $\mathrm{H}_{3}-13 \rightarrow \mathrm{C}-9, \mathrm{C}-10, \mathrm{C}-11, \mathrm{C}-12$; $\mathrm{H}_{3}-14 \rightarrow \mathrm{C}-6, \mathrm{C}-8 ; \mathrm{H}_{3}-15 \rightarrow \mathrm{C}-1$; (DMSO- $\left.d_{6}, 600 \mathrm{MHz}\right)$ $\mathrm{OH}-11 \rightarrow \mathrm{C}-10, \mathrm{C}-11, \mathrm{C}-12, \mathrm{C}-13$; HRESIMS $\mathrm{m} / \mathrm{z}$ 251.1391 (calcd. for $\mathrm{C}_{13} \mathrm{H}_{19} \mathrm{~N}_{2} \mathrm{O}_{3}, 251.1390$ ). 


\subsubsection{Fusagerin E (5)}

Pale yellow powder; UV (MeOH) $\lambda_{\max }(\log \varepsilon) 233$ (2.31), 293 (2.41) nm; IR (neat) $v_{\max } 3270$ (br), 2973, 1710, 1634, 1515, 1437, 1379, 1262, 1173, $1044 \mathrm{~cm}^{-1} ;{ }^{1} \mathrm{H}$ and ${ }^{13} \mathrm{CNMR}$ data see Table 3 ; HMBC data (acetone- $d_{6}, 500 \mathrm{MHz}$ ) $\mathrm{H}-2 \rightarrow \mathrm{C}-1, \mathrm{C}-4$; H-3 $\rightarrow$ C-1, C-2, C-4; H-6 $\rightarrow$ C-4, C-8; $\mathrm{H}-9 \rightarrow \mathrm{C}-4, \mathrm{C}-10, \mathrm{C}-11 ; \mathrm{H}-10 \rightarrow \mathrm{C}-8, \mathrm{C}-11, \mathrm{C}-12, \mathrm{C}-13$; $\mathrm{H}_{3}-12 \rightarrow \mathrm{C}-10, \mathrm{C}-11, \mathrm{C}-13 ; \mathrm{H}_{3}-13 \rightarrow \mathrm{C}-10, \mathrm{C}-11, \mathrm{C}-12$; $\mathrm{H}_{3}-14 \rightarrow \mathrm{C}-6, \mathrm{C}-8 ; \mathrm{H}_{3}-15 \rightarrow \mathrm{C}-1$; HRESIMS $m / z 267.1339$ (calcd. for $\mathrm{C}_{13} \mathrm{H}_{19} \mathrm{~N}_{2} \mathrm{O}_{4}, 267.1339$ ).

\subsubsection{Fusagerin $F(\boldsymbol{6})$}

Pale yellow powder; $\mathrm{UV}(\mathrm{MeOH}) \lambda_{\max }(\log \varepsilon) 236(1.91), 292$ (2.41) nm; IR (neat) $v_{\max } 3389$ (br), 2923, 1688, 1639, 1518, $1415,1382,1306,1274,1224,1196,1148 \mathrm{~cm}^{-1} ;{ }^{1} \mathrm{H}$ and ${ }^{13} \mathrm{C}$ NMR data see Table 3 ; HMBC data (DMSO- $d_{6}, 400 \mathrm{MHz}$ ) $\mathrm{H}-2 \rightarrow \mathrm{C}-1, \mathrm{C}-3, \mathrm{C}-4$; H-3 $\rightarrow$ C-1, C-2, C-4; H-6 $\rightarrow$ C-4, C-8, C-14; H-9 $\rightarrow$ C-4, C-8, C-10, C-11; 10-H $\rightarrow$ C-8, C-9, $\mathrm{C}-12, \mathrm{C}-13 ; \mathrm{H}_{3}-12 \rightarrow \mathrm{C}-10, \mathrm{C}-11, \mathrm{C}-13 ; \mathrm{H}_{3}-13 \rightarrow \mathrm{C}-10$, $\mathrm{C}-11, \mathrm{C}-12 ; \mathrm{H}_{3}-14 \rightarrow \mathrm{C}-6$, C-8; HRESIMS $\mathrm{m} / \mathrm{z}, 221.1293$ (calcd. for $\mathrm{C}_{12} \mathrm{H}_{17} \mathrm{~N}_{2} \mathrm{O}_{2}, 221.1285$ ).

\subsubsection{Fungerin (7)}

${ }^{1} \mathrm{H},{ }^{13} \mathrm{C}$ NMR, and the MS data were consistent with literature values [7].

\subsection{Computational Details}

Conformational analyses of each enantiomer of $\mathbf{1}$ and $\mathbf{2}$ were performed using Random Search method with MMFF94s force field and MMFF94 charges in Sybyl8.0 software. For each conformation of both compounds, TD-B3LYP/6$311++\mathrm{g}(2 \mathrm{~d}, \mathrm{p}) / / \mathrm{B} 3 \mathrm{LYP} / 6-31 \mathrm{G}(\mathrm{d})$ calculations yielded excitations with corresponding oscillator and rotational strength values performed with the program package Gaussian09 [17]. Then the overall CD spectra were summed up following the Boltzmann statistics, according to the respective heats of formation. For a better visualization, the rotational strengths were transformed into $\Delta \varepsilon$ values.

\subsection{Antimicrobial and Antifungal Bioassays}

Antimicrobial and antifungal bioassays were conducted in triplicate by following the National Center for Clinical Laboratory Standards (NCCLS) recommendations [20, 21]. The bacterial strains, Staphylococcus aureus (ATCC 6538), Streptococcus pneumoniae (CGMCC 1.1692), and Escherichia coli (CGMCC 1.2340) were grown on Mueller-Hinton agar, the yeasts, Candida albicans (ATCC 10231) and Geotrichum candidum (AS2.498), were grown on Sabouraud dextrose agar, and the fungus, Aspergillus fumigatus (ATCC 10894), was grown on potato dextrose agar. Targeted microbes (3-4 colonies) were prepared from broth culture (bacteria: $37{ }^{\circ} \mathrm{C}$ for $24 \mathrm{~h}$; fungus: $28^{\circ} \mathrm{C}$ for $48 \mathrm{~h}$ ), and the final spore suspensions of bacteria (in MHB medium), yeasts (in SDB medium), and Aspergillus fumigatus (in PDB medium) were $10^{6}, 10^{5}$ cells/ $\mathrm{mL}$, and $10^{4}$ mycelial fragments $/ \mathrm{mL}$, respectively. Test samples $(10 \mathrm{mg} / \mathrm{mL}$ as stock solution in DMSO and serial dilutions) were transferred to 96-well clear plate in triplicate, and the suspension of the test organisms was added to each well achieving a final volume of $200 \mu \mathrm{L}$ (ampicillin and fluconazole were used as positive controls). After incubation, the absorbance at $595 \mathrm{~nm}$ was measured with a microplate reader (TECAN). The inhibition rate was calculated and plotted versus test concentrations to afford the $\mathrm{IC}_{50}$, whereas the MIC was defined as the lowest test concentration that completely inhibited the growth of the test organisms.

\subsection{MTS Assay [52]}

In a 96-well plate, each well was plated with $(2-5) \times 10^{3}$ cells (depending on the cell multiplication rate). After cell attachment overnight, the medium was removed, and each well was treated with $100 \mu \mathrm{L}$ medium containing $0.1 \%$ DMSO, or appropriate concentrations of the test compounds and the positive control cisplatin $(100 \mathrm{mM}$ as stock solution of a compound in DMSO and serial dilutions; the test compounds showed good solubility in DMSO and did not precipitate when added to the cells). The plate was incubated for $48 \mathrm{~h}$ at $37{ }^{\circ} \mathrm{C}$ in a humidified, $5 \% \mathrm{CO}_{2}$ atmosphere. Proliferation assessed by adding $20 \mu \mathrm{L}$ of MTS (Promega) to each well in the dark, followed by a 90 min incubation at $37^{\circ} \mathrm{C}$. The assay plate was read at $490 \mathrm{~nm}$ using a microplate reader. The assay was run in triplicate.

Acknowledgments We gratefully acknowledge financial support from the National Natural Science Foundation of China (81273395) and the National Program of Drug Research and Development (2012ZX09301-003).

\section{Compliance with Ethical Standards}

Conflicts of Interest The authors declare no conflict of interest.

Open Access This article is distributed under the terms of the Creative Commons Attribution 4.0 International License (http:// creativecommons.org/licenses/by/4.0/), which permits unrestricted use, distribution, and reproduction in any medium, provided you give appropriate credit to the original author(s) and the source, provide a link to the Creative Commons license, and indicate if changes were made.

\section{References}

1. T. Henkel, R. Brunne, H. Müller, F. Reichel, Angew. Chem. Int. Ed. 38, 643-647 (1999) 
2. J.B. Gloer, Acc. Chem. Res. 28, 343-350 (1995)

3. J.B. Gloer, in The Mycota IV: Environmental and Microbial Relationships, ed. by D.T. Wicklow, B. Soderstrom (SpringerVerlag, Berlin, 1997), pp. 249-268

4. J. Meinwald, T. Eisner, Proc. Natl. Acad. Sci. USA 105, 4539-4540 (2008)

5. Y. Che, Int. J. Pharm. Res. 38, 12-27 (2011)

6. H. Guo, H. Hu, S. Liu, X. Liu, Y. Zhou, Y. Che, J. Nat. Prod. 70, 1519-1521 (2007)

7. Y. Zhang, S. Liu, X. Liu, Y. Che, J. Nat. Prod. 70, 1522-1525 (2007)

8. Y. Zhang, S. Liu, H. Liu, X. Liu, Y. Che, J. Nat. Prod. 72, 1364-1367 (2009)

9. E. Li, F. Zhang, S. Niu, X. Liu, G. Liu, Y. Che, Org. Lett. 14, 3320-3323 (2012)

10. J. Lin, S. Liu, B. Sun, S. Niu, E. Li, X. Liu, Y. Che, J. Nat. Prod. 73, 905-910 (2010)

11. C. Ma, Y. Li, S. Niu, H. Zhang, X. Liu, Y. Che, J. Nat. Prod. 74, 32-37 (2011)

12. J. Ren, F. Zhang, X. Liu, L. Li, G. Liu, X. Liu, Y. Che, Org. Lett. 14, 6226-6229 (2012)

13. S. Chen, F. Ren, S. Niu, X. Liu, Y. Che, J. Nat. Prod. 77, 9-14 (2014)

14. Y. Kato, H. Koshino, J. Uzawa, K. Anzai, Biosci. Biotech. Biochem. 60, 2081-2083 (1996)

15. R. Silverstein, G. Bassler, T. Morrill, Spectrometric Identification of Organic Compounds, 5th edn. (Wiley, Chichester, 1991)

16. R. Keyzers, C. Gray, M. Schleyer, C. Whibley, D. Hendricks, M. Davies-Coleman, Tetrahedron 62, 2200-2206 (2006)

17. M.J. Frisch, G.W. Trucks, H.B. Schlegel, G.E. Scuseria, M.A. Robb, J.R. Cheeseman, G. Scalmani, V. Barone, B. Mennucci, G.A. Petersson, H. Nakatsuji, M. Caricato, X. Li, H. Hratchian, A. Izmaylov, J. Bloino, G. Zheng, J. Sonnenberg, M. Hada, M. Ehara, K. Toyota, R. Fukuda, J. Hasegawa, M. Ishida, T. Nakajima, Y. Honda, O. Kitao, H. Nakai, T. Vreven, J. Montgomery, J. Peralta, F. Ogliaro, M. Bearpark, J. Heyd, E. Brothers, K.N. Kudin, V. Staroverov, R. Kobayashi, J. Normand, K. Raghavachari, A. Rendell, J.C. Burant, S.S. Iyengar, J. Tomasi, M. Cossi, N. Rega, J.M. Millam, M. Klene, J.E. Knox, J.B. Cross, V. Bakken, C. Adamo, J. Jaramillo, R. Gomperts, R.E. Stratmann, O. Yazyev, A.J. Austin, R. Cammi, C. Pomelli, J.W. Ochterski, R.L. Martin, K. Morokuma, V.G. Zakrzewski, G.A. Voth, P. Salvador, J.J. Dannenberg, S. Dapprich, A.D. Daniels, O. Farkas, J.B. Foresman, J.V. Ortiz, J. Cioslowski, D.J. Fox, Gaussian 09, Revision A. 01, 5th edn. (Gaussian, Inc., Wallingford, 2009)

18. M. Ono, T. Tsuru, H. Abe, M. Eto, M. Okawa, F. Abe, J. Kinjo, T. Ikeda, T. Nohara, J. Nat. Prod. 69, 1417-1420 (2006)

19. S. Homhual, N. Bunyapraphatsara, T. Kondratyuk, A. Herunsalee, W. Chaukul, J. Pezzuto, H. Fong, H. Zhang, J. Nat. Prod. 69, 421-424 (2006)

20. E. Li, L. Jiang, L. Guo, H. Zhang, Y. Che, Bioorg. Med. Chem. 16, 7894-7899 (2008)

21. G. Ding, Y. Li, S. Fu, S. Liu, J. Wei, Y. Che, J. Nat. Prod. 72, 182-186 (2009)

22. K. Friedrich, M. Zamkanei, R. Zimmer, J. Prakt. Chem. 38, 404-408 (2000)

23. H. Biltz, Ber. Dtsch. Ges. Chem. 1908, 1379-1393

24. H. Merritt, T. Putnam, Arch. Neurol. Psychiatry 39, 1003-1015 (1938)
25. C. López, G. Trigo, in Advances in Heterocyclic Chemistry, vol. 38, ed. by C. Brown, R. Davidson (Academic Press, New York, 1985), pp. 177-228

26. P. Back, P. Maurois, C. Dupont, N. Pages, J. Stables, P. Gressens, P. Evrard, J. Neurosci. 18, 4363-4373 (1998)

27. T. Rodgers, M. LaMontagne, A. Markovac, A. Ash, J. Med. Chem. 20, 591-594 (1977)

28. A. Khodair, Carbohydr. Res. 306, 567-573 (1998)

29. R. Comber, R. Reynolds, J. Friedrich, R. Manguikian, R. Buckheit, J. Truss, W. Shannon, J. Secrist, J. Med. Chem. 35, 3567-3572 (1992)

30. J. Knabe, J. Baldauf, A. Ahlhelm, Pharmazie 52, 912-919 (1997)

31. J. Menéndez, M. Díaz, C. Bellver, M. Söllhuber, Eur. J. Med. Chem. 27, 61-66 (1992)

32. M. Tompkins, J. Med. Chem. 29, 855-859 (1986)

33. K. Kieć-Kononowicz, E. Szymańska, Il Farmaco 57, 909-916 (2002)

34. J. Marton, J. Enis, S. Hosztafi, T. Tímár, J. Agric. Food Chem. 41, 148-152 (1993)

35. G. Chen, Y. Lin, L. Vrijmoed, W. Fong, Chem. Nat. Compd. 42, 138-141 (2006)

36. T. Liu, Z. Li, Y. Wang, L. Tian, Y. Pei, H. Hua, Nat. Prod. Res. 25, 1596-1599 (2011)

37. H. Brastianos, E. Vottero, B. Patrick, R. Soest, T. Matainaho, A. Mauk, R. Andersen, J. Am. Chem. Soc. 128, 16046-16047 (2006)

38. M. Tsuda, T. Yasuda, E. Fukushi, J. Kawabata, M. Sekiguchi, J. Fromont, J. Kobayashi, Org. Lett. 8, 4235-4238 (2006)

39. S. Carmelya, M. Llanb, Y. Kashmana, Tetrahedron 45, 2193-2200 (1989)

40. G. Chan, S. Mong, M. Hemling, A. Freyer, P. Offen, C. DeBrosse, H. Sarau, J. Westley, J. Nat. Prod. 56, 116-121 (1993)

41. K. Alvi, B. Peters, H. Lisa, C. Phillip, Tetrahedron 49, 329-336 (1993)

42. I. Mancini, G. Guella, C. Debitus, F. Pietra, Helv. Chim. Acta 78, 1178-1184 (1995)

43. A. Plubrukarn, D. Smith, R. Cramer, B. Davidson, J. Nat. Prod. 60, 712-715 (1997)

44. B. Copp, C. Fairchild, L. Cornell, A. Casazza, S. Robinson, C. Ireland, J. Med. Chem. 41, 3909-3911 (1998)

45. X. Fu, F. Schmitz, R. Tanner, M. Kelly-Borges, J. Nat. Prod. 61, 384-386 (1998)

46. H. Gross, S. Kehraus, G. König, G. Woerheide, A. Wright, J. Nat. Prod. 65, 1190-1193 (2002)

47. S. Tsukamoto, T. Kawabata, H. Kato, T. Ohta, H. Rotinsulu, R. Mangindaan, R. van Soest, K. Ukai, H. Kobayashi, M. Namikoshi, J. Nat. Prod. 70, 1658-1660 (2007)

48. N. Cachet, G. Genta-Jouve, E. Regalado, R. Mokrini, P.G. Amade, G. Culioli, O. Thomas, J. Nat. Prod. 72, 1612-1615 (2009)

49. H. Kang, W. Fenical, Tetrahedron Lett. 37, 2369-2372 (1996)

50. A. Visconti, M. Solfrizzo, J. Agric. Food Chem. 42, 195-199 (1994)

51. R. Uchida, R. Imasato, Y. Yamaguchi, R. Masuma, K. Shiomi, H. Tomoda, S. Ōmura, J. Antibiot. 58, 804-809 (2005)

52. N. Zhang, Y. Chen, R. Jiang, E. Li, X. Chen, Z. Xi, Y. Guo, X. Liu, Y. Zhou, Y. Che, X. Jiang, Autophagy 7, 598-612 (2011) 